\title{
Understanding Financial Inclusion in Vietnam
}

\author{
Tran Hung Son ${ }^{1}$, Nguyen Thanh Liem ${ }^{1} \&$ Huynh Thi Ngoc Ly ${ }^{1}$ \\ ${ }^{1}$ Institute for Development and Research in Banking Technology, University of Economics and Law, VNU-HCM, \\ Ho Chi Minh City, Vietnam \\ Correspondence: Tran Hung Son, Institute for Development and Research in Banking Technology, University of \\ Economics and Law, VNU-HCM, Ho Chi Minh City, Vietnam, 669 National Route 1A, Quarter 3, Linh Xuan Ward, \\ Thu Duc District, Ho Chi Minh City, Vietnam. Tel: 84-909-224-879.
}

Received: November 29, 2019

Accepted: December 9, 2019

Online Published: December 15, 2019

doi:10.5430/rwe.v10n3p382

URL: https://doi.org/10.5430/rwe.v10n3p382

\begin{abstract}
The objective of this paper is to analyze the factors that affect the financial inclusion in Vietnam using the World Bank's Global Findex dataset. Analytical results show that income affects the use of official accounts and official savings. Education is positively correlated with official accounts and official savings, but is negatively correlated with the use of formal credit. Age influences official savings and the use of formal credit and this relationship is nonlinear. Sex does not impact the use of official and official savings accounts. However, being a woman tends to use formal financial channels more. The reason for not owning official accounts of individuals in Vietnam is mainly subjective (related to personal income). Being a woman and being older are less likely to use informal credit, while the lowest income-group people tend to use informal credit. From the results of this research, some policy implications are outlined to promote financial inclusion in Vietnam.
\end{abstract}

Keywords: financial inclusion, individual characteristics, access to finance, Vietnam

\section{JEL: G20; G28}

\section{Introduction}

In recent years, the establishment of inclusive financial system which serves the society becomes an important policy in several countries, especially emerging economies. Financial inclusion is defined as a service offering suitable and convenient financial benefits for individuals, households and businesses. In other words, financial inclusion raises an opportunity for businesses and individuals to access to financial market in order to foster human resource's distribution and usage efficiently. Further, economy is encouraged to grow up and the gap between the rich and the poor is diminished. Financial inclusion helps individuals to plan for saving in the future and financial stability in countries are maintained as saving ratio will increase which support banking system to survive stably in crisis (Han and Melecky, 2013).

However, according to CGAP (2010), there are 2.6 billions of people living in developing countries have not approached banking services due to not owning bank account and less than $30 \%$ of the world population is able to access to credit. Therefore, it is not persuasive to conclude that banking services are ubiquitous the majority of people. In 2014, World Bank's Global Findex shows that the rate of those who have their own bank account is $30.9 \%$ and this figure is lower than middle-low income countries (41.8\%) and even much lower than the average in the world (60.7\%). In comparison with ASEAN's countries, individual bank account's ratio in Vietnam is only higher than Philippines, Laos, Myanmar and Cambodia. Therefore, State Bank of Vietnam has cooperated with World Bank to build up a national strategy for financial inclusion since 2016. Vietnam is listed as one of 25 countries promoting financial inclusion and until 2020 since Vietnam population is dense whereas using financial inclusion rate is low. The objective is to help people who have not experienced banking services to access formal financial system. Hence, adults are able to open a trading account and this is the first stage towards financial inclusion. As a result, residents enable to use financial services that they are in demand as saving, payment, borrowing and insurance. Financial inclusion for millions of people who have not or rarely used financial services is considered as a means of achieving both goals: reducing poverty and fostering Vietnam economy which are declared in the report Vietnam 2035.

In this very context, to promote and facilitate financial inclusion in Vietnam, there is a need for an empirical study that provides evidence to the understanding of financial inclusion in Vietnam. The current study makes a major contribution in this sense. The objective of this study is to analyze the factors affecting financial inclusion in Vietnam employing World Bank's Global Findex data. In addition, the study also analyzes financial exclusion; how 
large source of borrowing is influenced by individual's characteristics as gender, education level, age and income in Vietnam

Probit regression with robust standard errors is used to estimate how individuals' characteristics are associated with financial inclusion in Vietnam. The results reveal that individual determinants of financial inclusion in Vietnam are comparable to what is observed by other studies based on data from all around the world.

\section{Literature Review}

Up to now, there has not been a general definition to define Financial Inclusion; however, this term has been adjusted and finalized based on different perspectives of particular circumstances in which financial inclusion is applied. Financial inclusion is the trend in which formal financial services (bank account, saving and credit) are approached at reasonable fees by all people including whose income is low (Hannig and Jansen 2010; Khan, 2011 and Sarma, 2015). Therefore, financial inclusion is normally defined under three factors: formal account, formal saving and using credit issued by a formal financial intermediary (Demirgüc-Kunt and Klapper, 2013).

Factors related to individual's characteristics impact on financial inclusion in plenty of nations are income, age, gender and education level (Demirgüc-Kunt and Klapper, 2013; Allen and ctg, 2012; Fungácová and Weill, 2015). Besides, Aleen et al (2012) clarifies many subjective barriers that influence on financial inclusion as religion, income... (Depend on individual's characteristics) and objective barriers as fees, places... (Depend on financial system).

Schneider and Enste (2000) states informal finance is a part of informal economy. Steel and ctg (1997) explain the reasons why informal finance exist: (1) over intervention from the governments lead to underdeveloped financial system; (2) Banks have to deal with costly procedures and management problems, which reduce approaching credit from public. De Koker and Jentzsch (2013) identifies that using formal financial services does not prevent the development of informal financial service. Fungácová and Weill (2015) also shows that individual's characteristics (age, income, education level and gender) influence on access to formal financial services.

A number of studies in association with household attributes and how they impact on approaching formal financial services. Djankov et al (2008) use data of household issued by Mexican Ministry of Agriculture. The results report that households owning bank accounts and spending higher living costs have more properties and higher education level. Beck and Brown (2010) analyze European Bank for Reconstruction and Development (EBRD)'s data to evaluate factors affect to approaching towards financial inclusion. From previous studies, the capability of owning a bank account has a positive correlation with income, property, education level of most of households in many countries. Additionally, the authors conclude that religions, ethnic minorities and regions (urban or countryside), likewise, impact on access to finance.

Turvey and Kong (2010) examine data set conducted by 1,500 agricultural households to compare then decide between formal borrowing and informal borrowing. The result shows a positive relationship between trust and informal credit, mistrust and formal credit. The proportion of farming households who borrow directly from their family and friends accounts for $67 \%$; it means that informal borrowing is a crucial source of credit for agricultural households.

Karlan et al. (2009) figure out trust is an important determinant towards informal borrowing thanks to relationships in Peru. Hoff and Stiglitz (1993) suggest that asymmetric information among people in a community is much less than in comparison to formal borrowing. That explains why people prefer informal borrowing since informal borrowing is simpler than formal one.

World Bank's Global Findex's data is run by Demirgüc-Kunt and Klapper (2013) to analyze usage of financial service in several countries based on three components as owning bank account, formal saving in banks and using banking credit. As a result, income is a primary factor which influences on financial inclusion. Allen et al (2012) investigate the effect of individual's characteristics and national features on owning a bank account and saving in banks through 123 countries. Financial inclusion is driven by income and education level factors.

Fungácová and Weill (2015) analyze financial inclusion in China, including comparisons with Brazil, Russia, India and South Africa. The study identifies that higher income, better education, being a man, and being older are associated with greater use of formal accounts and formal credit in China. Income and education influence the use of alternative sources of borrowing.

\section{Methodology}

In this paper, data are collected by interviewing 1,000 respondents who are relevant to experiencing financial services, usage objectives and source of informal finance in Vietnam published by World Bank in association with including demographics as individual's income, education level, age and gender. 
Three factors suggested by Demirgüc-Kunt and Klapper (2013) are employed to evaluate financial inclusion of individuals in Vietnam. Owning an account in a formal financial institution (formal account) is the first factor. This determinant is identified according to the question:" Do you own a formal account in any formal financial institution?" Financial inclusion combines several appearances in which owning a formal account issued by a formal institution is essential. It is important that an individual has an account as it is a channel to access to bank services; therefore, individuals enable to open their saving account and borrow from financial institutions. The second factor involves in saving in a formal financial institution (formal saving) and it is clarified through the question:" Have you had saving in any bank or micro financial institution over the past 12 months?" The answer for this factor provides information about the willingness of saving in formal financial institutions compared to other types of saving. The third factor is how individuals use the source of capital from financial institutions (formal credit). The question:" Have you ever borrowed from any bank or micro financial institution over the past 12 months?" is raised to figure out the last factor.

In addition to three mentioned factors, the interview refers to "Would you mind telling the reason why you have not opened a bank account or a financial institution's account?" in order to investigate financial barriers towards financial inclusion.

Informal financial source is defined by relevant information about borrowing transactions within 12 months: installment purchase, borrowing from relatives and friends, loan shark etc.

In this paper, we examine the data of individuals' characteristics conducted by Global Findex to analyze the impact of these characteristics on Vietnam financial inclusion, financial inclusion's barriers and informal finance. In this paper, Probit regression model was used to estimate the following equations for indices related to financial inclusion, the following equation is estimated:

$$
X_{i}=\alpha+\beta^{*} \text { gender }_{i}+\gamma^{*} \text { age }_{i}+\delta^{*} \text { education }_{i}+\delta^{*} \text { income }_{i}+\varepsilon_{i}
$$

$\mathrm{X}$ represents for variables which measure financial inclusion and $i$ is an individual's index. Different characteristics of individuals are explanatory variables and they are classified into four groups: gender, age, education and income.

For gender variable, if the respondent is female, it is coded as 1 ; otherwise, the coded number is 0 . The age variable is measured by two variables: number of years (age) and squared age $\left(\mathrm{age}^{2}\right)$ to examine nonlinearity in the association with both age and financial inclusion (Fungácová và Weill, 2015).

For education level variable, two dummy variables are considered including secondary education and tertiary education. If the individual complete secondary education or tertiary education, the variable equals to 1 ; otherwise, it equals to 0 . If respondents have primary education or lower level, the dummy variable is omitted.

Income is indicated by including four dummy variables, each equal to one if the individual's income is in a given quintile, group 1 is low income (the poorest); group 2 is lower middle income; group 3 is middle income; group 4 is higher middle income and group 5 is high income (the richest). The omitted dummy variable is for the fifth income quintile.

We first estimate equation (1) for the main indicators of financial inclusion and then continue with analyses of the other indicators

\section{Results}

\subsection{Determinants Impact on Measurement Towards Financial Inclusion}

Table 1 presents marginal effects for the probit estimations in the relation with financial inclusion in Vietnam where dependent variables include formal account, formal saving and formal credit.

The results investigate that gender does not affect to own a bank account and saving, which implies that financial inclusion is not influenced by gender. These findings are in line with the work of Allen et al (2012). The relationship between gender and using financial services in worldwide does not exist. However, based on the result, being a woman uses formal credit much more frequently than being a man and these results are inconsistent with the study of Fungácová và Weill (2015). In line with the result, an implication for financial institutions is to appeal to women using their individual's credit.

Age has a negative effect on owning an account or a formal account in Vietnam. Additionally, it shows that adults use formal account less than others in Vietnam. We find significant effects for $A g e$ and $A g e^{2}$, which are respectively positive and negative with using formal credit. Hence, nonlinear relationship exists in association with age and using formal credit. People who are older tend to use formal credit with higher rate; however, it only affects until getting equilibrium. The result can be explained by the supply and demand of "generation effect". Elderly people who have not experienced formal credit are hesitate towards using its financial services. Therefore, financial institution should 
not attempt strongly to elderly people group, which is identical the findings from Allen et al (2012) and Fungácová and Weill (2015). The relation between age and owning a formal account does not survive.

Education has a positive correlation with owning a formal account. Both dummy variables as secondary education and tertiary education are in the same direction towards owning a formal account and are meaningful. Further, education level in line with tertiary education affect positively on formal saving. However, the relation between education and using formal credit are negative, which is different from usual awareness. This result does not support the perspective that higher- education-level people prefer using formal credit more frequently.

The estimations show that using a formal account and having a formal saving relate to individual's income in Vietnam. Dummy variables belonging to the first three groups of income variable impact negatively and are statistical meaning. These findings are in line with Demirgüc-Kunt and Klapper (2013) and Fungácová and Weill (2015). Their papers conclude that income moves in the same direction as financial inclusion; therefore, the poor are more difficult than the rich in financial access. However, we do not find statistical evidences between income and using formal credit in Vietnam.

In general, the probit examinations present individual's characteristics influence on financial inclusion in Vietnam. First, income affects to have formal account and formal saving. Secondly, the relation between education and owning formal account and formal saving are positive. Otherwise, education moves negatively towards using formal credit. Third, age impacts on formal saving and using formal credit and this is a nonlinear relation. Forth, gender does not have effect on using formal account and formal saving. However, being a woman would rather use formal credit.

Table 1. Determinants of financial inclusion

\begin{tabular}{llll}
\hline & Formal account & Formal saving & Formal credit \\
\hline Female & 0.00393 & -0.0284 & $0.0542^{* *}$ \\
Age & $(0.16)$ & $(1.32)$ & $(2.2)$ \\
& $-0.00428^{* * *}$ & -0.00029 & $0.00163 *$ \\
Age $^{2}$ & $(4.72)$ & $(0.36)$ & $(1.67)$ \\
& -0.000 & $-0.0002^{* * *}$ & $-0.0004^{* * *}$ \\
Secondary education & $(0.82)$ & $(3.41)$ & $(7.28)$ \\
& $0.0894^{* * *}$ & 0.0307 & -0.0236 \\
Tertiary education & $(3.02)$ & $(1.15)$ & $(0.86)$ \\
& $0.439^{* * *}$ & $0.204 * * *$ & $-0.105 * *$ \\
Group 1 & $(11.38)$ & $(6.21)$ & $(2.16)$ \\
& $-0.202^{* * *}$ & $-0.161^{* * *}$ & 0.0365 \\
Group 2 & $(4.85)$ & $(4.18)$ & $(0.93)$ \\
& $-0.171^{* * *}$ & $-0.0755^{* *}$ & -0.0199 \\
Group 3 & $(4.31)$ & $(2.29)$ & $(0.50)$ \\
& $-0.114^{* * *}$ & $-0.120^{* * *}$ & -0.00587 \\
Group 4 & $(3.04)$ & $(3.61)$ & $(0.15)$ \\
& -0.0549 & -0.0457 & -0.0208 \\
\hline Observation & $(1.50)$ & $(1.53)$ & $(0.55)$ \\
pseudo R & 1000 & 993 & 998 \\
\hline
\end{tabular}

Source: Author's calculation from research data.

Notes: ${ }^{*}, * *$, and $* * *$ represent the significance levels at $10 \%, 5 \%$, and $1 \%$, respectively.

Numbers in parentheses are t-values. 


\subsection{Determinants of Barriers to Financial Inclusion}

In this section, we analyze individual's characteristics in line with explanations why people do not have accounts in financial institutions (formal account). Refer to analysis from previous section, having accounts in financial institutions are key to financial inclusion. Allen et al (2012) investigates that responses' combining these terms as "lack of money", "religious reasons", "family member has one" express subjective perspectives (depend on individual's characteristics). On the other hand, questions involved in: too far away (places), too expensive, lack of documentation, lack of trust are objective (depend on financial system). It is vital to differentiate subjective and objective causes since it is relevant to policy makers. The authors explain separate reason out of 7 barriers which impact on financial inclusion based on 4 individual's characteristics. Table 2 shows estimations

This paper does not seek out the relationship between gender and the reason why people do not own any formal account in Vietnam. Age affects to own formal account and elderly people are less impacted by owning formal account due to plenty of reasons: "too far away", "too expensive", "lack of documentation" and "religion".

There is a highlighted in the association between education and barriers in financial access. The regression's result shows that education and using formal account are inverse proportion in view of "too far away", "not have enough money"," religion". Otherwise, estimations indicates that education and formal account are direct proportion by cause of "lack of trust" and "family member has one". Therefore, people who acquire higher education do not own account in financial institutions if their family member has been owned an account. Further, they are sensitive to trust in financial intermediary when that open an account. In line with these exploration, it can be implied that as Vietnamese education becomes higher, the relation from civilian towards financial institutions will be changed. The trust in financial institutions is an important standard. Moreover, financial system's issues impacts heavily to the trust of people who obtain higher-education level.

Income affects to own formal account, as expected and the reason "not have enough money" explains why the poor do not own formal accounts. Estimations show that coefficient of two variables group 1 and 2 (low income and low-middle income) remain positive; low-income group has the highest coefficient. This result is identical to the study of Fungácová and Weill (2015). In addition, religion influences on owning formal account of the poor in different direction (negative relation) due to not having enough money. People whose lower income are less likely impacted by "religion" factor compared with high-income ones. In line with the cause "family member has one", this study does not find out the interaction between income and owning formal account. For other objective reasons "too far away", "too expensive", "lack of documentation", "lack of trust", the regression result does not reflect the relation with income. Middle-income people (group 3) are less directed by "to expensive" complaint. This result shows that objective reasons do not have influence on the poorest people's demand.

Table 2. Determinants of barriers to financial inclusion

\begin{tabular}{llllllll}
\hline & Too far away & $\begin{array}{l}\text { Too } \\
\text { expensive }\end{array}$ & $\begin{array}{l}\text { Lack of } \\
\text { documentation }\end{array}$ & Lack of trust & Religion & $\begin{array}{l}\text { Not have } \\
\text { enough } \\
\text { money }\end{array}$ & $\begin{array}{l}\text { Family } \\
\text { member } \\
\text { has one } \\
\text { account }\end{array}$ \\
\hline Female & -0.0238 & -0.0061 & 0.0122 & 0.0058 & 0.0114 & 0.033 & 0.0081 \\
& $(0.94)$ & $(0.34)$ & $(0.98)$ & $(0.45)$ & $(0.79)$ & $(0.91)$ & $(0.27)$ \\
Age & $-0.0032^{* * *}$ & $-0.0013^{*}$ & $-0.0017 * * *$ & 0.0005 & $-0.0009^{*}$ & -0.0002 & $0.0019^{*}$ \\
& $(3.67)$ & $(1.95)$ & $(3.66)$ & $(1.04)$ & $(1.82)$ & $(0.17)$ & $(1.70)$ \\
Age $^{2}$ & 0.0000 & -0.0000 & $0.0000^{* * *}$ & $-0.0000^{* *}$ & 0.0000 & -0.0000 & -0.0000 \\
& $(0.55)$ & $(0.81)$ & $(3.91)$ & $(1.98)$ & $(1.42)$ & $(1.15)$ & $(1.07)$ \\
Secondary & & & & & & & \\
education & $-0.0525^{*}$ & -0.0273 & -0.00427 & 0.0152 & $-0.0339^{*}$ & $-0.157^{* * *}$ & 0.0427 \\
& $(1.88)$ & $(1.37)$ & $(0.28)$ & $(1.13)$ & $(1.89)$ & $(4.09)$ & $(1.30)$ \\
Tertiary & 0.0000 & 0.0000 & 0.0000 & & & & $0.145 *$
\end{tabular}




\begin{tabular}{llllllll} 
Group 1 & 0.0191 & 0.0168 & -0.0131 & -0.0198 & 0.0000 & $0.192 * * *$ & -0.0455 \\
& $(0.45)$ & $(0.59)$ & $(0.59)$ & $(0.94)$ & $(0.0000)$ & $(3.25)$ & $(0.93)$ \\
Group 2 & 0.0583 & 0.0341 & -0.0148 & -0.019 & $-0.0342^{*}$ & $0.133^{* *}$ & -0.0176 \\
& $(1.44)$ & $(1.23)$ & $(0.71)$ & $(0.93)$ & $(1.65)$ & $(2.24)$ & $(0.36)$ \\
Group 3 & -0.026 & $-0.0728 *$ & -0.0123 & -0.0235 & 0.0000 & 0.0545 & -0.0198 \\
& $(0.60)$ & $(1.90)$ & $(0.59)$ & $(1.15)$ & $(0.0000)$ & $(0.91)$ & $(0.41)$ \\
Group 4 & -0.0128 & -0.00324 & -0.0108 & -0.0149 & -0.0024 & 0.0785 & 0.0107 \\
& $(0.28)$ & $(0.10)$ & $(0.51)$ & $(0.74)$ & $(0.16)$ & $(1.26)$ & $(0.22)$ \\
\hline $\mathrm{N}$ & 681 & 669 & 688 & 701 & 376 & 715 & 712 \\
pseudo R-sq & 0.041 & 0.06 & 0.162 & 0.059 & 0.133 & 0.048 & 0.013 \\
\hline
\end{tabular}

Source: Author's calculation from research data.

Notes: *,*, and *** represent the significance levels at $10 \%, 5 \%$, and $1 \%$, respectively.

Numbers in parentheses are t-values.

\subsection{Determinants of Sources of Borrowing}

Vietnam issues an important policy so that the poor are capable of access to credit. Recent survey has indicated that credit access is considered as a difficult problem of small enterprises. Further, household credit fund is still limited, whereas most of banking funds are financing for state-owned enterprises (Center party economic commission, 2017). World Bank's Global Findex 2014 statistics indicate that individual borrowing rate in formal financial institutions in the last 12 months accounts for only $18.4 \%$ while individual borrowing rate within 12 months is $46.8 \%$. These numbers lead to a question whether individuals in Vietnam are over dependent on informal credit or not. Then, the authors analyze how individual's characteristics affect to use informal credit in Vietnam, for instance, "installment purchase", "borrowing from family and friends", "private lender". After that, we distinguish between using formal credit and using informal credit.

Table 3 reports the results that being a woman less borrows from family and friends than male. Additionally, being a woman tends to increase borrowing from formal financial institutions whereas this proportion decreases towards informal finance $(5.42 \%$ and $-5.25 \%$, respectively). This finding is not similar to the study of Fungácová and Weill (2015) in China since they conclude that gender does not affect to decide informal credit or formal financial credit. On the other hand, age determines choosing borrowing from family and friends as older people would rather borrow from family and friends. Additionally, the ratio of borrowing from formal financial institutions is higher than informal finance towards older people.

Education indicates that secondary-education respondents less use the source of borrowing from "loan shark". However, analytical result indicates that those having tertiary education less use formal borrowing. Higher-education level does not equal to better financial access in Vietnam (dummy variables of education do not have statistical meaning in order to explain for using informal borrowing).

Income factor does not affect the use of informal credit sources from "installment purchases" and "private lender". However, for informal credit sources and "borrowing from family or friends", the results show that people with the lowest income (group 1) increase the probability of using this source of credit more than people having the highest income.

The analytical results show that individual's characteristics (income, age, gender) impact on informal credit sources that becomes common, especially borrowing from family and friends. 
Table 3. Determinants of sources of borrowing

\begin{tabular}{llllll}
\hline & $\begin{array}{l}\text { Installment } \\
\text { purchases }\end{array}$ & $\begin{array}{l}\text { Family and } \\
\text { friends }\end{array}$ & private lender & Informal credit & Formal credit \\
\hline Female & -0.0124 & $-0.0552^{* *}$ & 0.0037 & $-0.0525^{*}$ & $0.0542^{* *}$ \\
\hline & $(1.38)$ & $(1.97)$ & $(0.47)$ & $(1.85)$ & $(2.2)$ \\
\hline Age & -0.0004 & $-0.005^{* * *}$ & -0.0005 & $-0.0051^{* * *}$ & $0.0016^{*}$ \\
\hline Age $^{2}$ & $(1.12)$ & $(5.01)$ & $(1.46)$ & $(4.99)$ & $(1.67)$ \\
\hline & -0.0000 & $-0.0002^{* * *}$ & -0.0000 & $-0.0002^{* * *}$ & $-0.0004^{* * *}$ \\
\hline Secondary education & $(0.43)$ & $(3.51)$ & $(1.60)$ & $(3.77)$ & $(7.28)$ \\
\hline & 0.00828 & 0.0276 & $-0.0287^{* *}$ & 0.0155 & -0.0236 \\
\hline Tertiary education & $(0.79)$ & $(0.86)$ & $(2.47)$ & $(0.48)$ & $(0.86)$ \\
\hline & 0.000 & 0.0252 & -0.00269 & 0.0277 & $-0.105^{* *}$ \\
\hline Group 1 & $(0.000)$ & $(0.48)$ & $(0.24)$ & $(0.53)$ & $(2.16)$ \\
\hline & 0.0158 & $0.105^{* *}$ & 0.0129 & $0.122^{* * *}$ & 0.0365 \\
\hline Group 2 & $(1.23)$ & $(2.29)$ & $(0.99)$ & $(2.64)$ & $(0.93)$ \\
\hline & -0.00299 & 0.0041 & 0.00447 & 0.0145 & -0.0199 \\
\hline Group 3 & $(0.20)$ & 0.09 & $(0.30)$ & 0.31 & $(0.50)$ \\
\hline & -0.00591 & 0.04 & 0.00062 & 0.0398 & -0.00587 \\
\hline Group 4 & $(0.40)$ & $(0.92)$ & $(0.05)$ & $(0.9)$ & $(0.15)$ \\
\hline & 0.00766 & 0.0356 & 0.00909 & 0.0457 & -0.0208 \\
\hline $\mathrm{N}$ & $(0.60)$ & $(0.83)$ & $(0.72)$ & $(1.05)$ & $(0.55)$ \\
\hline pseudo R-sq & 890 & 997 & 996 & 1000 & 998 \\
\hline & 0.047 & 0.045 & 0.08 & 0.045 & 0.077 \\
\hline Soure: & & & &
\end{tabular}

Source: Author's calculation from research data.

Notes: $* * *$, and $* * *$ represent the significance levels at $10 \%, 5 \%$, and $1 \%$, respectively.

Numbers in parentheses are t-values.

\section{Conclusions}

In this paper, we analyze the factors influencing on financial inclusion in Vietnam based on the data set of World Bank's Global Findex. Financial inclusion is important since it boosts economic growth in line with poverty reduction, higher education and entrepreneurship. We obtain several insightful results:

- Individual's characteristics affecting financial inclusion in Vietnam are income, education, gender and age. There is a gap in financial inclusion when the poor less access to finance than the rich. Women and people at the certain age prefer formal credit. Highly-educated people use more formal account and formal saving whereas they less use the formal credit.

- Financial inclusion barriers in Vietnam (formal account) are subjective reasons: income (not have enough money) or family member has one and the objective reason is financial institutions are far from their livings. This implies that policymakers in Vietnam should concentrate on developing a network of financial intermediaries. In terms of socio-economic conditions, the lowest income people (group 1) is the group with the lowest rate in access to financial services. Highly-educated people do not use accounts in financial institutions if their family members have owned account and they consider "trust" towards financial intermediaries when opening accounts.

- Family and friends is the first thought if they decide to borrow money, which makes up of $29 \%$ for people who are older than 15 years old in comparison to $18.4 \%$ of individuals living in Vietnam using formal credit. 
Being a woman at a certain age less uses informal credit sources; however, poorer individuals tend to use informal credit.

From this analysis, we suggest some implications for policy to foster financial inclusion in Vietnam.

- The poor are subject to plenty of difficulties in personal financial inclusion (income barrier). The new approach is to support the poor not only in formal financial services, which Vietnam Bank for Social Policies are implementing, but also non-financial demands to complement the use of financial resources through financial education programs to keep up with the overall standard development in community. To achieve goals, the government must foster development policies and raise funds for financial education programs towards entire population.

- Vietnam Bank for Social Policies (VBSP), established in 2003, is a key credit provider to low-income households and rural areas. However, the majority of customers live in remote areas where difficulties arise (geographic barriers). As a result, VBSP is unable to serve the financial demands of the majority of the population together with limiting offering banking financial services, except for credit services. This means that VBSP has not yet kept pace with the trend of microfinance worldwide. To improve this situation, through the successful experiences from a number of countries in the region, the government needs to issue more supportive policies for banking projects interacting through mobile phone platforms, digital applications that VBSP is currently implementing to improve access to finance in Vietnam.

- Informal financial source, for example, borrowing from family and friends still plays an important role in Vietnam. However, it should be highlighted that relying on informal credit and less using of formal credit in the long term reduce economic growth since borrowing ability of individuals is reduced. On the other hand, using informal credit increases financial instability (these credit sources are less subject to the supervision of the authorities). Therefore, policy makers need to define policies to regulate informal credit under specific laws and regulations towards this market.

- For financial institutions, it is advisable to focus on attracting young people and women in using their financial services. In addition, the analysis results show that qualified people are interested in trust in the financial institutions they perform. Therefore, building trust in a financial soundness system for the public encourages the use of formal financial credit sources in Vietnam.

This study only uses cross-sectional data, so the variation across time is not available, and it is a single country study. Further studies could enrich the data by including more countries to examine whether there are differences in the above links across economies, or to build the panel data for Vietnamese observations. As mentioned earlier, this study uses the three main financial inclusion indicators; therefore, other studies could analyze digital financial inclusion - digital access to, and the use of, formal financial services - to test the robustness of the results of this study.

\section{Acknowledgment}

This research is funded by University of Economics and Law, Vietnam National University Ho Chi Minh City, Vietnam.

\section{References}

Allen, F., Demirgüc-Kunt, A., Klapper, L., \& Peria, M. (2012). The Foundations of Financial Inclusion: Understanding Ownership and Use of Formal Accounts. World Bank Policy Research Paper 6290, World Bank.

Ban Kinh tế Trung ương. (2017). Chẩn đoán tăng truởng kinh tế Việt Nam. Nhà xuất bản Thông tin và truyền thông.

Beck, T., \& Brown, M. (2010). Which households use banks? Evidence from the transition economies. European Banking Center Discussion Paper No. 2010-25. Tilburg, The Netherlands.

CGAP (Consultative Group to Assist the Poor). (2010). Financial Access 2010: The State of Financial inclusion through the crisis. Washington, DC: CGAP.

De Koker, L., \& Jentzsch, N. (2013). Financial inclusion and financial integrity: aligned incentives?. World Development, 44, 267-280.

Demirgüc-Kunt, A., \& Klapper, L. (2012). Measuring Financial Inclusion: The Global Findex Database. World Bank Policy Research Working Paper.

Demirgüc-Kunt, A., \& Klapper, L. (2013). Measuring Financial Inclusion: Explaining Variation in Use of Financial Services Across and Within Countries. Brookings Papers on Economic Activity, 279-340. 
Djankov, S., Miranda, P., Seira, E., \& Sharma, S. (2008). Who are the unbanked?. World Bank Policy Research Working Paper 4647. Washington DC.

Fungáčová, Z., \& Weill, L. (2015). Understanding Financial Inclusion in China. China Economic Review, 34, 196-206.

Han, R.., \& Melecky, M. (2013). Financial Inclusion for Financial Stability: Access to Bank Deposits and the Growth of Deposits in the Global Financial Crisis. World Bank Policy Research Working Paper 6577, World Bank.

Hannig, A., and S. Jansen. (2010). Financial Inclusion and Financial Stability: Current Policy Issues. ADBI Working Paper 259. Tokyo: Asian Development Bank Institute.

Hoff, K., \& Stiglitz, J. E. (1993). Imperfect information and rural credit markets: puzzles and policy perspectves. In K. Hoff, A Braverman, \& J. E. Stiglitz (Eds.), The Economics of Rural Organization: Theory, Pactice, and Policy. New York, NY: Oxford UniversityPress.

Karlan, D., Mobius, M., Rosenblat, T., \& Szeidl, A. (2009). Trust and social collateral. The Quarterly Journal of Economics, 112(4), 1251-1288.

Khan, H. R. (2011). Financial Inclusion and Financial Stability: Are They Two Sides of the Same Coin?. Address by Shri H. R. Khan, Deputy Governor of the Reserve Bank of India, at BANCON 2011, organized by the Indian Bankers Association and Indian Overseas Bank, Chennai, India, 4 November.

Sarma, M. (2015). Measuring fnancial inclusion. Economics Bulletin, 35(1), 604-611.

Schneider, F., \& Enste, D. H. (2000). Shadow economies: size, causes, and consequences. Journal of Economic Literature. 38, 77-114.

Steel, W. F., Aryeetey, E., Hettige, H., \& Nissanke, M. (1997). Informal financial markets under liberalization in four African countries. World Development, 25, 817-830

Turvey, C. G., \& Kong, R. (2010). Informal lending amongst friends and relatives: Can microcredit compete in rural China?. China Economic Review, 21, 544-556.

World Bank. (2008). Finance for Policies and pitfalls in expanding access. Washington, DC: World Bank. 